\title{
Teacher Profession Development on Technology Integration Using the Mastery of Active and Shared Learning for Techno-Pedagogy (MASLEPT) Model
}

\author{
Michael Nkwenti Ndongfack \\ Department of Computer Science and Educational Technologies, Higher Teacher Training College Yaounde, \\ University of Yaounde I, Yaounde, Cameroon \\ Email: mikesman2002@yahoo.com
}

Received 15 February 2015; accepted 5 March 2015; published 9 March 2015

Copyright (C) 2015 by author and Scientific Research Publishing Inc.

This work is licensed under the Creative Commons Attribution International License (CC BY).

http://creativecommons.org/licenses/by/4.0/

(c) () Open Access

\section{Abstract}

As various learning technologies increasingly become available in schools, teachers are not using them for instructional purposes. Many studies have indicated that one of the reasons for which teachers do not use the tools is because they have not been effectively trained. The purpose of this study was to experiment the use of the MASLEPT school-based professional development model in updating primary school teachers' knowledge of technology, pedagogy and content (TPACK). The study employed a single group pre-training and post-training quasi-experimental design methodology in the collection of quantitative data from 52 teacher-participants from four separate schools located in the same campus. The data were meant to evaluate their TPACK after 10 weeks of professional development programme. The results indicated teacher-participants who took part in the experiment demonstrate a significant improvement in their TPACK. To test whether improvement had any statistical significant difference, the mean of the pre-training and posttraining results were compared using the t-test. The findings indicated that $p=0.005<0.05$. It was therefore concluded that there was a statistically significant difference between the scores. Therefore teacher-participants' TAPCK improved as a result of their participation in the professional development programme. This finding was further triangulated by comparing the scores of the lesson notes produced by the teacher-participants with the post-training scores. It was found that the scores of each construct of the lesson notes were better than the post-training scores. This led to the recommendation that the MASLEPT school-based model be adopted for teacher professional development on technology integration in instructional processes.

\section{Keywords}

Technology Pedagogy Content Knowledge, Technology Integration Model, 


\section{Introduction}

In 2007, the Cameroon Ministry of Basic Education put in place an Information Communication Technology (ICT) Policy and Strategy Plan outlining guidelines for the development of ICT in schools. The plan envisaged the production of an ICT-literate workforce which will acquire thinking, learning and communications skills to respond to the demands of the 21st century. With a clear policy objectives put in place to develop ICT across the school curriculum, the government and her development partners are gradually equipping schools with the required ICT resources (Nkwenti Ndongfack, 2010). Although ICTs are gradually being made available in classrooms, most schools with no electricity, computers and internet connection continue to be left behind. Teachers who have access to ICT in their schools under-utilise the resources for instructional purposes. Pupils from rich backgrounds with access to computers and internet connection at home are more technology-savvy than their teachers. This category of pupils poses a lot of challenges to their teachers when it comes to using technology in classrooms (Inspectorate of Pedagogy in Charge of ICT Annual Report, 2011). Teachers' inability to handle this category of pupils has been largely blamed on little or no professional development (Fru, 2011; Karsenti, Collin, \& Harper-Merrete, 2012). The lack of these skills and technological resources significantly inhibits the use of ICT tools in teaching and learning.

For teachers to be able to use technological tools in their classrooms, an effective ongoing professional development programme must be put in place to improve their skills (MacDonald, 2009). Several studies have proven that effective teacher professional development leads to the enhancement of teachers' knowledge and skills (Hanley, Maringe, \& Ratcliffe, 2008; Lieberman \& Pointer-Mace, 2008). Fraser (2005), Yoon, Duncan, Lee, Scarloss and Shapley (2007) affirmed that effective teacher professional development contributes to pupils' improved learning outcomes. The improvement in pupils' academic achievement is the ultimate aim of teacher professional development (Borko, 2004; Guskey \& Sparks, 2002; Rock \& Wilson, 2005). This paper evaluates primary school teachers' knowledge of technology, pedagogy and content after engaging them in a 10-week school-based professional development programme using the Mastery of Active and Shared Learning Processes for Techno-pedagogy model and concludes with recommendations for stakeholders.

\section{Challenges in the Use of ICT in Instructional Processes}

Since the integration of ICT in the Cameroon primary school curriculum, some studies have been conducted to ascertain how prepared teachers were and how they were using the tool in pedagogic practices (Fru, 2011; Karsenti et al., 2012; Inspectorate of Pedagogy in Charge of ICT Annual Reports, 2010; Nkwenti Ndongfack, 2010). The Inspectorate of Pedagogy in Charge of ICT Annual Reports (2009; 2010; 2011) has repeatedly observed that since the introduction of ICT in the Cameroon primary school curriculum in 2008, teachers have not received any effective professional development on the use of the tool. Nkwenti Ndongfack (2010) conducted a study on the classroom use of ICT in some public primary schools in Cameroon and the findings revealed that:

- teachers hardly use the tool to support learning across the curriculum;

- the use of ICT for instructional processes has not kept pace with the increasing availability of the tool;

- teachers lack technology pedagogic-integration skills.

Confirming these views, other studies observed that despite the availability of computers in some schools, teachers were not using them to teach (Inspectorate of Pedagogy in Charge of ICT Annual Report, 2010). Viewing ICT as a stand-alone subject, teachers' believe that ICT should be taught only by trained computer teachers. Other studies have also been conducted on the Cameroon primary school state-of-readiness in terms of availability of resources and teachers' skills in using ICT for pedagogic purposed (Fru, 2011; Karsenti et al., 2012). The findings revealed that most schools lack ICT resources and infrastructures. The schools that had the resources, most teachers did not have the skills to integrate technology in instructional processes.

The model of professional development adopted for training of teachers on the use of ICT for instructional purposes has been unusually short, lasting for just a day. The one day training takes place once in three months within the Ministry of Basic Education's pedagogic day seminars. The one-day seminar is often held in the Inspectorate of Primary Education or in a nearby school where all participants converged. This approach to teacher 
professional development has been criticised by many researchers as being brief, fragmented, incoherent, decontextualized and isolated from real classroom situations (Schwille \& Dembélé, 2007; Villegas-Reimers, 2003). The lack of an adequate professional development model on the adoption of technology in classrooms has been a major challenge to teachers.

These findings seem to indicate that the ineffective model of teacher professional development has led to the lack of skills to integrate technology in the teaching and learning process. In this researcher's opinion as an ICT Pedagogic Supervisor for nine years in the same Ministry, this is one major factor that impedes teachers' adoption of technology in their classrooms. Although several researchers have made allusion to factors influencing teachers' adoption of ICT in classroom practices, no further studies have been conducted to determine the kind of professional development and the types of knowledge they will need to effectively adopt technology in their classrooms. Based on the challenges observed in teacher professional development on technology integration, this study was conducted with the following research question in mind:

What are teachers' knowledge of technology, pedagogy and content after their participation in the Mastery of Active and Shared Learning Processes for Techno-pedagogy school-based professional development model?

\section{Contemporary Trends in Teacher Profession Development on Technology Integration}

Mishra and Koehler (2006) have demonstrated that the 21st century teachers need three kinds of knowledge to effectively adopt ICT in their classrooms notably: technology, pedagogy and content. Without an effective on-going professional development of teachers on these knowledge domains, teachers might not be able to use technology adequately. Training of teachers in contemporary educational practices is thus a key aspect in almost every education improvement strategy and constitutes the main component of educational reform programmes (Valanides \& Angeli, 2006; MacDonald, 2009). The ICT Policy and Strategy Plan for Basic Education (2007) recognise this and uphold that

Professional development is an aspect which much attention needs to be accorded. For ICTs to be smoothly integrated in the curriculum, educators need continuous professional development. In this regard, the Ministry will ensure that in service teachers and administrators receive regular professional development (p.14).

Valanides and Angeli (2006) remarked that the task of training teachers on how to effectively integrate ICT in classroom practices is undoubtedly complex. A review of literature indicates that for the most part, ICT professional development for teachers has mostly centred on learning about ICT, the main focus being skills development on the use of various computer applications, such as word processing, spread sheets, email, internet, graphics, etc. Although basic computing skills constitute the cornerstone of ICT knowledge, skills-based courses are not enough to prepare teachers to integrate ICT in classroom instruction as they are usually taught in isolation from a pedagogical context (Harris, Mishra, \& Koehler, 2009; Becker \& Riel, 2001; Selinger, 2001). Professional development models that do not take into consideration subject-specific pedagogy and the context of application will lead to teachers having difficulties to link technology with pedagogy (Harris et al., 2009). This accounts for the reasons why many teachers who received ICT training as part of their professional development still lack the confidence needed to integrate ICT in the teaching and learning process (Harris et al., 2009; Harrison, Comber, Fisher, Haw, Lewin, Lunzer, McFarlane, Mavers, Scrimshaw, Somekh, \& Watling, 2002).

The improvement of teachers' Technological Pedagogical Content Knowledge (TPACK) is one of the most important investments of time which educational systems or governments can make in education (Holland, 2005). Harris and Hoffer (2011) remarked that for teachers to integrate technology across different subject areas in the school curriculum, they need to demonstrate a firm mastery of TPACK. TPACK is an amalgamation of teachers' knowledge of curriculum content, general pedagogies, technologies, and contextual factors that influence learning (Koehler \& Mishra, 2008). TPACK is an extension of Shulman's $(1986,1987)$ notion of pedagogical content knowledge - the specialized knowledge required to teach differently within different subject areas-which revolutionized our understanding of teacher knowledge and its development. Because of its revolutionizing nature in today's classroom practices, most professional development programmes are now focusing on developing teachers' TPACK to overcome the challenge they face and also as a strategy to prepare teachers to effectively adopt technology (Lee, Suharwoto, Niess, \& Sadri, 2006; Richardson, 2009). Teacher professional development with a focus on blending technology, pedagogy and content knowledge is yet to be implemented in the Cameroon 
educational system. Therefore, there is a need to assess in-service primary school teachers' training needs in terms of technology, pedagogy and content knowledge in order to administer a professional development programme that empowers them to effectively adopt technology in their classrooms.

\section{Theoretical Framework}

Figure 1 is the theoretical framework adopted for this study. The Mastery of Active and Shared Learning Processes of Techno-pedagogy (MASLEPT) is a school-based professional development model (Nkwenti Ndongfack, 2015). MASLEPT was developed based on teachers' views and evidence from literature review on best practices in teacher training on technology integration in instructional processes. Literature upholds that an effective professional development model on technology integration should be characterised by teachers' pedagogical content knowledge; provision of sufficient time and resources; promotion of collegiality and collaborative exchange; include follow up procedures; models high quality instruction and be school-based (Nkwenti Ndongfack, 2015). In this regards, three key factors come into play.

Firstly, Mishra and Koehler (2006) as cited in Nkwenti Ndongfack (2015) uphold that teachers' Technological Pedagogical Content Knowledge (TPACK) is paramount in any teaching and learning process. TPACK framework constitutes three knowledge domains and seven constructs notable Technology Knowledge (TK); Pedagogy Knowledge (PK); Content Knowledge (CK); Pedagogical content knowledge (PCK); Technological Content Knowledge (TCK); Technological Pedagogical Knowledge (TPK); and Technological Pedagogical Content Knowledge (TPACK. It provides a framework for understanding the complexity of integrating technology into specific subject matter.

Secondly, Nkwenti Ndongfack (2015) argues that Lesson Study is a well-documented school-based teacher professional development model which originated from Japan in the 18th century (Baba \& Kojima, 2004; Fernandez \& Yoshida, 2004; Hashimoto, Tsubota, \& Ikeda, 2003). The underlying principle of the model requires groups of teachers to meet regularly over an extended period of time, to work on the design, implementation, feedback, and improvement of one or several "research lessons". Research lessons are authentic instructional packages taught by the teacher to their own class (Lewis \& Tsuchida, 1997).

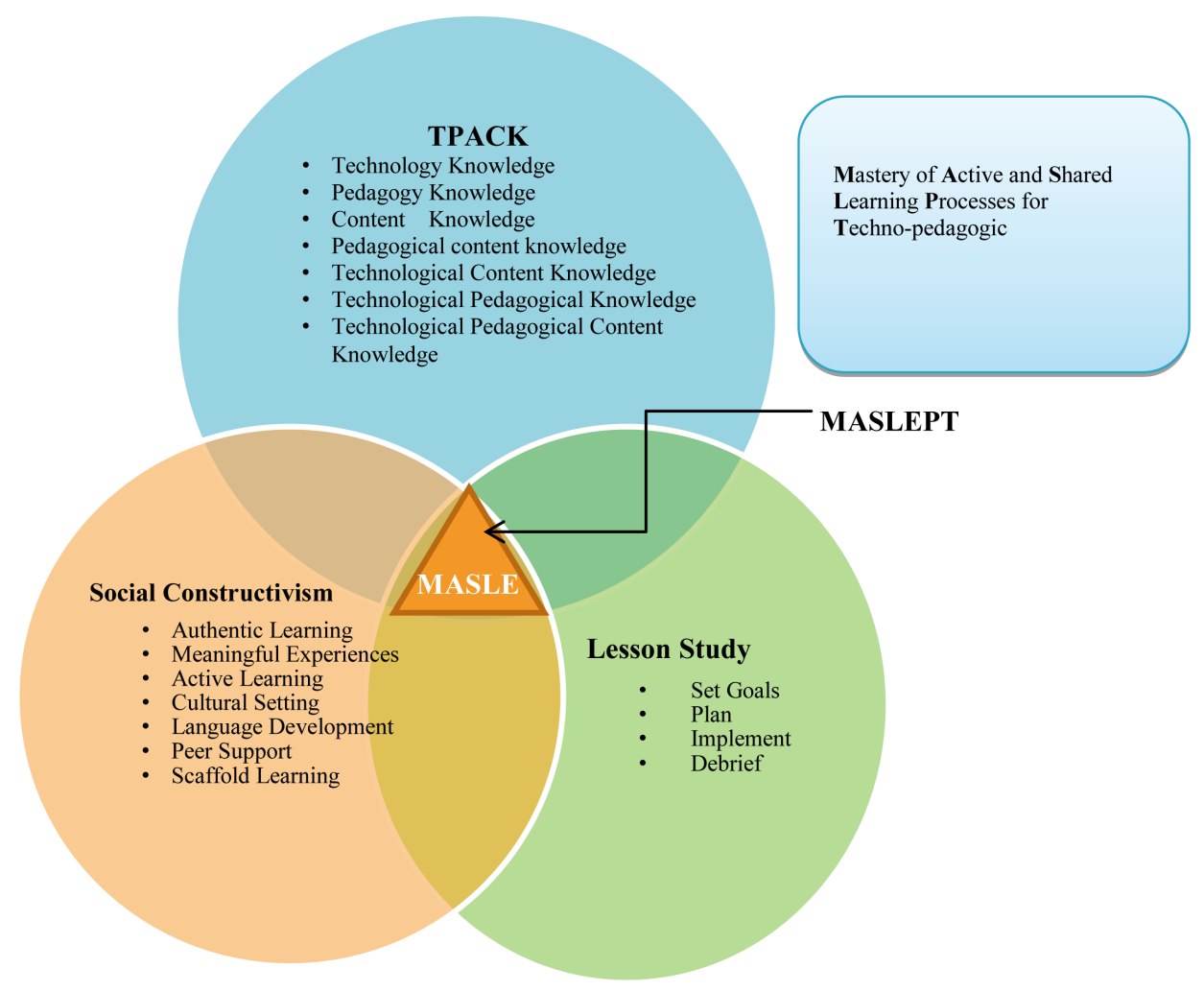

Figure 1. Mastery of active and shared learning processes for techno-pedagogy (MASLEPT) model. 
Thirdly, social constructivism is one of the most appropriate theoretical frameworks that support the teacher professional development model (Nkwenti Ndongfack, 2015). Dewey (1916) suggested that experience is the cornerstone from which new knowledge is created, promoting authentic learning and meaningful experiences that foster new knowledge growth. This perspective gave rise to a theoretical perspective known as constructivism. Widely accepted within the educational community, constructivism describes learning as a process whereby learners actively construct or build new ideas, concepts, or knowledge objects based upon existing understandings. Vygotsky (1962), a cultural psychologist theorized that language and conceptual development are linked to social phenomena and cultural contexts. Vygotsky (1978) extended the perspectives of constructivism by theorizing that learning occurs through sociocultural mediation, meaning that individuals construct new knowledge through their active participation within a social context and via interactions with its signs and tools. Social constructivism recognises that teachers grow from a relationship with a trusted confidant with whom they can establish and continue dialogue about ways of developing their understandings (Nkwenti Ndongfack, 2015). It guided the design of interactive activities that teachers' undertook throughout a professional development programme.

The MASLEPT model motivates teachers to participate, contribute, guide each other's learning, and give meaning to their common course of developing technology integration skills (Nkwenti Ndongfack, 2015). It establishes a common ground which gives teachers the motivation to meet, discuss and share their views on how to improve their pupils' learning outcomes through the use of technology in their classrooms. In so doing, the model contributes in defining the identity of the teachers because coming together for a common purpose implies a commitment to shared competencies that distinguishes them from others. As they engage in the model, they will undertake common activities, share ideas, reflect on their experiences and support each other. Their participation in these activities and the relationships that they create enable them to learn from each other and grow professionally.

The MASLEPT model also draws inspiration from a community of practice. Wenger, McDermott and Snyder (2002) as cited Nkwenti Ndongfack (2015) proposed that the terms "community of practice" refer to "a very specific type of social structure with a very specific purpose" (p. 41). The specific purpose within the framework of this study is the development of technology integration skills by in-service primary school teachers to enable them prepare pupils to respond to the demands of the 21st Century society. Members of a community of practice are "informally bound by what they do together" (Wenger, 1998: p. 2 in Nkwenti Ndongfack, 2015). They interact and learn together by engaging in joint activities around their shared domain of interest (Gray, 2004 in Nkwenti Ndongfack, 2015). The existence of these common situations, problems and perspectives is what brings teachers together to share knowledge and to learn from each other as they develop technology integration skills.

\section{Methodology}

This study targeted all 58 teacher-participants teaching in four separate schools located in the Government Central Primary School campus situated in the Yaounde 3 Sub-Division. A total of 52 teacher-participants volunteer to take part in the study. This population was made up of 12 males and 40 females drawn from the four schools. Single group pre-training and post-training quasi-experimental design was employed to evaluate the teacherparticipants knowledge of technology, pedagogy and content prior to and after they took part in the MASLEPT model.

Before the training of teacher-participants began, a meeting was convened to brief the school administration and the teaching staff on the purpose of the study. After the meeting, the researcher administered the pre-training survey questionnaire to 52 teachers who volunteered to take part in the study to determine their entry level. To fill the identified gaps, a professional development programme was co-designed with teacher-participants' to develop their knowledge of technology, pedagogy and content as an amalgamation. The course guideline of the programme was developed by the researcher who has a background in instructional design and technology. The course was aimed at providing teacher-participants with opportunities to gain the knowledge and skills needed to integrate technology into classroom practices. The content was structured into two units, eight topics with several objectives spread over a period of ten weeks with 2 hours of study per week conducted in a face-to-face mode.

The initial draft of the course materials was evaluated by two subject matter experts as one of the five approaches used in validating instructional design models and products (Richey, 2005; Richey \& Klein, 2007). The implementation of the professional development programme went on for ten weeks guided by the MASLEPT model. As a product of the professional development programme, teacher-participants developed lesson plans that integrate technology at the end of each topic. The lesson plans were used to verify teacher-participants' 
self-reported knowledge of technology, pedagogy and content. At the end of the ten-week programme, the researcher administered the post-training survey questionnaire.

\subsection{Data Collection}

Data collection instruments were made up of demographic items related to name of the school, gender, age and teaching experience; Seven Technology Knowledge (TK) items; Twelve Content Knowledge (CK) items; Seven Pedagogical Knowledge (PK) items; Four Pedagogical Content Knowledge (PCK) items; Four Technological Content Knowledge (TCK) items; Four Technological Pedagogical Knowledge (TPK) items; and Six Technological Pedagogical Content Knowledge (TPACK) items. Each item in the first and second sets of questionnaires was rated with a 5-point Likert-scale. The test items were designed to investigate their knowledge of technology, pedagogy and content as an amalgamation (Schmidt, Baran, Thompson, Koehler, Mishra, \& Shin, 2009; Archambault \& Crippen, 2009). They were administered to 52 teacher-participants before and after their participation in a single group pre-training and post-training experimental study.

The post-training scores were triangulated with the scores of lesson plans produced at the end of the professional development programme. The lesson plans were evaluated by two independent assessors to confirm their performances in the self-reported survey questionnaires. Technology Integration Assessment Rubric was used to evaluate technology-driven lesson plans developed by the teacher-participants during their participation in the professional development programme (Harris, Grandgenett, \& Hofer, 2010). The assessment rubrics focused on evaluating a blend of technology, pedagogy and content knowledge in lesson plans.

\subsection{Results}

What are teachers' knowledge of technology, pedagogy and content after their participation in the Mastery of Active and Shared Learning Processes for Techno-pedagogy school-based professional development model?

Table 1 presents the demographic information of the teacher-participants in terms of gender, age and teaching experience. With a total of 52 teacher-participants who took part in the study, 40 (76.9\%) were females and 12 (23.1\%) were males. A total of 2 (3.8\%) females participants were between 23 and 26 years. Meanwhile for the 27 to 32 years age bracket, $9(17.3 \%)$ were females and $3(5.8 \%)$ were males. For age 32 and above, there were 29 (55.8\%) females and 9 (17.3\%) males.

As regards their teaching experiences, 6 (11.6\%) females and 3 (5.8\%) males participants had a teaching experience of between 2 to 5 years. Since ICT was introduced in the primary school curriculum in 2007, teachers within the 2 to 5 years of teaching experience had been trained on how to use the tool in their classrooms in their pre-service training programmes. Another 11 (21.1\%) females and 3 (5.8\%) males participants had taught for between 6 to 10 years. Again, 2 (3.8\%) males and 12 (23.1\%) females participants teaching experiences ranged between 11 to 15 years. Finally, 11 (21.1\%) females and 7 (7.7\%) males had taught for 15 years and above. The cohort of teachers whose teaching experience six years and above were never exposed to any ICT module during their pre-service programme. They are those who have a lot of difficulties mainstreaming technology in instructional processes. Notwithstanding, it can be noted that the number of years of experience were almost equally distributed among the four age groups.

Figure 2 indicates the results of the pre-training scores of the 52 teacher-participants in seven constructs presented in terms of mean and standard deviation. It can be observed that the constructs of Content Knowledge (CK), Pedagogical Knowledge (PK), and Pedagogical Content Knowledge (PCK) all scored higher mean (M > 4.00) with a small standard deviation (Std. < 1.00). The constructs of Technological Knowledge (TK), Technological Content Knowledge (TCK), Technological Pedagogical Knowledge (TPK), and Technological Pedagogical Content Knowledge (TPACK) scored a small mean $(\mathrm{M}<3.00)$ with a slightly higher standard deviation $($ Std. $\leq 1.03)$. A small standard deviation indicates that there was very little variation or deviation from the mean.

Figure 3 depicts teacher-participants' post-training scores of the 52 teacher-participants in seven constructs presented in terms of mean and standard deviation. Three constructs: Pedagogical Knowledge (PK); Content Knowledge (CK); and Pedagogical Content Knowledge (PCK) recorded higher mean $(\mathrm{M}>4.00)$ and a small standard deviation (Std. < 0.5). On the other hand, the constructs of Technological Knowledge (TK); Technological Content Knowledge (TCK); Technological Pedagogical Knowledge (TPK); and Technological Pedagogical 
Table 1. Demographic information of teacher-participants.

\begin{tabular}{|c|c|c|c|c|c|}
\hline \multirow[t]{2}{*}{ Description } & & \multicolumn{2}{|c|}{ Male } & \multicolumn{2}{|c|}{ Female } \\
\hline & & Frequency & Percentage & Frequency & Percentage \\
\hline Participants & & 12 & 23.1 & 40 & 76.9 \\
\hline \multirow[t]{4}{*}{ Age } & $23-26$ & 00 & 00 & 2 & 3.8 \\
\hline & $27-32$ & 03 & 5.8 & 09 & 17.3 \\
\hline & $\geq 32$ years & 09 & 17.3 & 29 & 55.8 \\
\hline & 2 - 5 years & 03 & 5.8 & 06 & 11.6 \\
\hline \multirow{3}{*}{ Teaching experience } & 6 - 10 years & 03 & 5.8 & 11 & 21.1 \\
\hline & 11 - 15 years & 02 & 3.8 & 12 & 23.1 \\
\hline & $\geq 15$ years & 04 & 7.7 & 11 & 21.1 \\
\hline
\end{tabular}

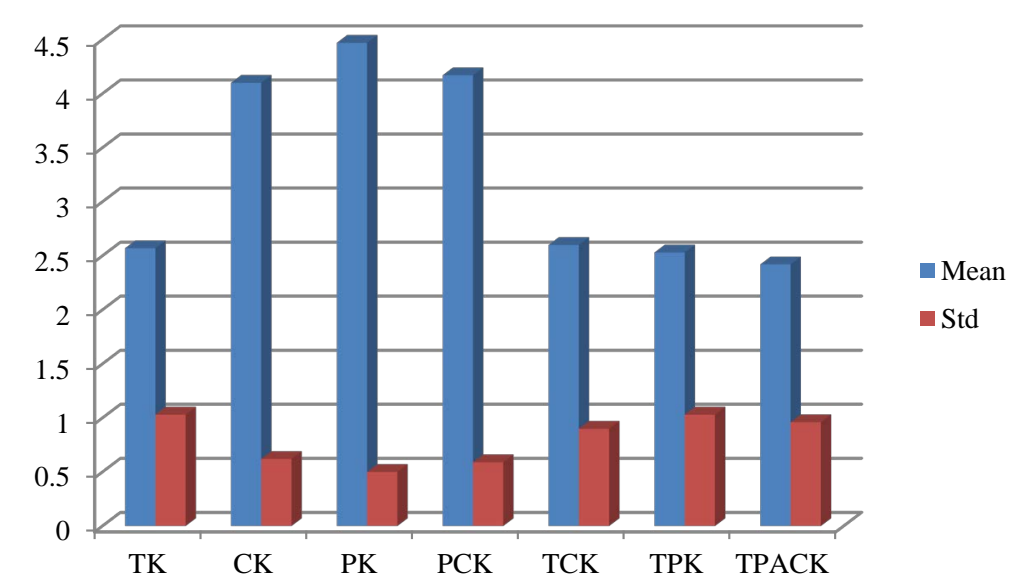

Figure 2. Mean and standard deviation of each construct in the pre-training.

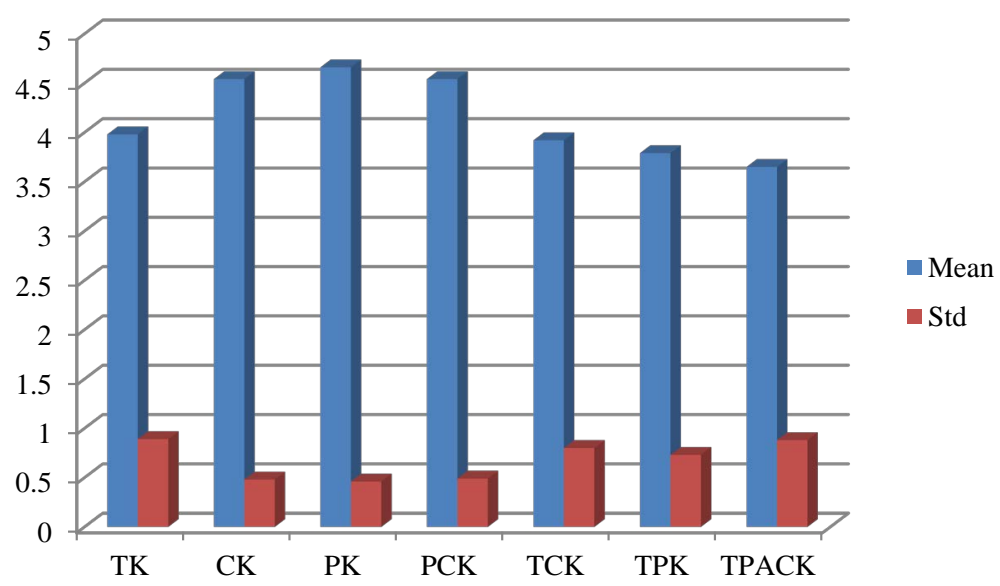

Figure 3. Mean and standard deviation of post-training constructs.

Content Knowledge (TPACK) recorded slightly lower mean $(M<4.00)$ than the previous three constructs. The standard deviation is slightly higher (Std. < 1.00). A small standard deviation indicates that there was very little variation or deviation from the mean.

Table 2 compares the mean of the pre-training and post-training scores. The table indicates the mean and standard deviation of all the seven constructs at pre-training and post-training. Comparing pre-training and posttraining scores, it can be observed that there was an improvement in both the mean (M2) and standard deviation (STD2) at post-training. 
Table 2. Mean and standard deviation of pre-training and post-training.

\begin{tabular}{cccccc}
\hline Construct & $\mathbf{N}$ & $\begin{array}{c}\text { Mean } \\
\text { (M1) }\end{array}$ & $\begin{array}{c}\text { Mean } \\
\text { (M2) }\end{array}$ & $\begin{array}{c}\text { Std. Deviation } \\
\text { (STD1) }\end{array}$ & $\begin{array}{c}\text { Std. Deviation } \\
\text { (STD2) }\end{array}$ \\
\hline TK & 52 & 2.57 & 3.98 & 1.03 & 0.89 \\
CK & 52 & 4.10 & 4.54 & 0.62 & 0.48 \\
PK & 52 & 4.47 & 4.66 & 0.50 & 0.46 \\
PCK & 52 & 4.17 & 4.54 & 0.59 & 0.49 \\
TCK & 52 & 2.60 & 3.92 & 0.90 & 0.80 \\
TPK & 52 & 2.53 & 3.79 & 1.03 & 0.73 \\
TPACK & 52 & 2.42 & 3.65 & 0.96 & 0.88 \\
\hline
\end{tabular}

Figure 4 compare the mean (M1 and M2) of TK, CK, PK, PCK, TCK, TPK and TPACK recorded during the pre-training and the post-training. M1 is the mean of each construct recorded during the pre-training and M2 represents the mean of each construct recorded during the post-training. At a glance, it can be observed that the mean of each construct in the post-training improved as compared to those of the pre-training. From the chart it can be observed that the constructs of TK, TCK, TPK and TPACK improved more than the other constructs because the professional development programme focused more on them. To confirm if there is any statistically significant difference, the paired sample t-test was used.

Table 3 points out the descriptive statistics of the variables being tested for statistical significance. The variables here represent the mean (M1) of pre-training scores and the mean (M2) of post-training scores. The means (M1) and (M2) of the 7 constructs (TK, CK, PK, PCK, TCK, TPK and TPACK) is $(\mathrm{M} 1=3.26)$ with a standard deviation of (STD1 $=0.92)$ and $(\mathrm{M} 2=4.15)$ with a standard deviation of (STD2 = 0.15). The mean M2 is higher than M1, an indication that teacher-participants reported an increase in their knowledge of technology, pedagogy and content.

Table 4 indicates the correlation between the variables being tested. The correlation between the two means (M1 and M2) of the 7 constructs (TK, CK, PK, PCK, TCK, TPK and TPACK) is 0.98 with a significance value of 0.00 . This indicates that there is no relationship between the two means (M1 and M2). Therefore changes in second mean (M2) is not strongly correlated with the first mean (M1).

Table 5 presents the results of the paired-sample t-test. It can be observed that the t-statistic value is -4.45 ; degree of freedom is 6 ; 2-tailed significance value is 0.005 . The difference between the 2 means is -0.88 with a standard deviation of 0.52 . The $95 \%$ confidence interval for the difference ranged from -1.37 to -0.40 . Since $p=0.005<0.05$, it can be concluded that there is a statistically significant difference between the two means. Therefore the change observed in the post-training mean is due to the professional development intervention involving the independent variables (TK, CK, PK, PCK, TCK, TPK and TPACK).

Although the t-test is statistically significant, the teacher-participants' knowledge of technology, pedagogy and content questionnaires were self-reported. The post-training scores were triangulated with the scores of lesson plans produced at the end of the professional development programme. The lesson plans were evaluated by two independent assessors to confirm their performances in the self-reported survey questionnaires.

Table 6 shows the inter-rater reliability scores in different components of the lesson plans. It can be observed that the inter-rater reliability score ranged between 0.62 and 0.82 . From Cohen Kappa's rule of the thumb, values of Kappa ranging from 0.40 to 0.59 are considered moderate, 0.60 to 0.79 substantial, and 0.80 outstanding. Based on these interpretation guidelines, it can be concluded that the two assessors had substantial agreement in all the constructs of the lesson plans. Based on these guidelines, the two assessors substantially agreed on the evaluation of PK, CK, PCK, TPK and TPACK constructs. Regarding the evaluation of TK and TCK constructs, the assessors strongly agreed. In this regard, Table 6 presents the percentage counts, percentages, mean and standard deviation of lesson plans developed by teacher-participants during their participation in the professional development programme.

Table 7 shows the performances of teacher-participants in lesson plans developed during the professional development programme. It can be observed that 10 (83.3\%) of the lesson plans produced by teacher-participants had the subject matter of the lesson designed correctly and appropriately spelt out. Similarly, 10 (83.3\%) of the lesson plans had appropriate pedagogic approaches to support learning. Additionally, 7 (58.3\%) of the lesson 


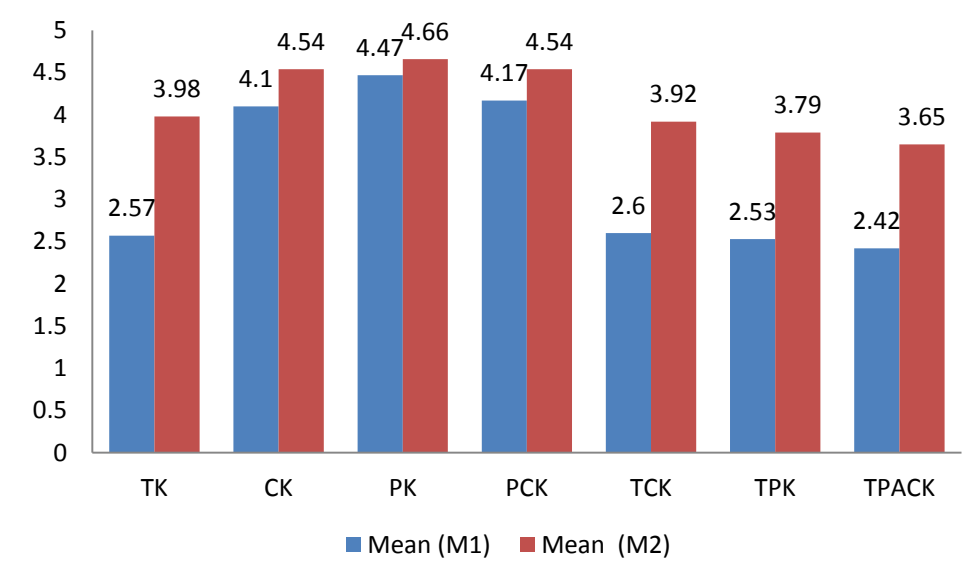

Figure 4. Mean of the pre-training and post-training constructs.

Table 3. Paired-sample statistics.

\begin{tabular}{cccccc}
\hline & Variables & Mean & N & Std. Deviation & Std. Error Mean \\
\hline \multirow{2}{*}{ Pair 1 } & Mean (M1) & 3.26 & 7 & 0.92 & 0.35 \\
& Mean (M2) & 4.15 & 7 & 0.41 & 0.15 \\
\hline
\end{tabular}

Table 4. Paired-sample correlations.

\begin{tabular}{ccccc}
\hline & Variables & N & Correlation & Sig. \\
\hline Pair 1 & Mean (M1) \& Mean (M2) & 7 & 0.98 & 0.00 \\
\hline
\end{tabular}

Table 5. Paired-sample test.

\begin{tabular}{|c|c|c|c|c|c|c|c|c|c|}
\hline & & \multicolumn{5}{|c|}{ Paired Differences } & \multirow{3}{*}{$\mathrm{t}$} & \multirow{3}{*}{$\mathrm{df}$} & \multirow{3}{*}{$\begin{array}{l}\text { Sig. } \\
\text { (2-tailed) }\end{array}$} \\
\hline & & \multirow{2}{*}{ Mean } & \multirow{2}{*}{ Std. Deviation } & \multirow{2}{*}{$\begin{array}{l}\text { Std. Error } \\
\text { Mean }\end{array}$} & \multicolumn{2}{|c|}{$\begin{array}{l}\text { 95\% Confidence Interval of } \\
\text { the Difference }\end{array}$} & & & \\
\hline & & & & & Lower & Upper & & & \\
\hline Pair 1 & M1 - M2 & -0.88 & 0.52 & 0.19 & -1.37 & -0.40 & -4.45 & 6 & 0.005 \\
\hline
\end{tabular}

Table 6. Inter-rater reliability scores in each construct of the lesson plans.

\begin{tabular}{ccc}
\hline Constructs & Kappa \\
\hline CK & 0.75 \\
PK & 0.75 \\
TK & 0.83 \\
PCK & 0.67 \\
TCK & 0.83 \\
TPK & 0.62 \\
TPACK & 0.62 \\
\hline
\end{tabular}

plans were clearly designed and used computer applications that enhanced the lesson comprehension. In the same view, 7 (58.3\%) of the lesson plans had appropriate blend of content and pedagogic approaches to achieve the goals of the lesson. The teacher-participants also ensured that 6 (50\%) of the lesson plans aligned computer applications with the goals of the lesson. In 8 (66.7\%) of the lesson plans, teacher-participants used computer applications appropriately to support teaching approaches. Finally, 8 (66.7\%) of the lesson plans demonstrated appropriate blend of content, pedagogy and computer applications within the lesson plan. These results indicate a small standard deviation (standard deviation $<0.55$ ). A small standard deviation indicates that the data is 
Table 7. Assessment of lesson plans developed during the professional development programme.

\begin{tabular}{|c|c|c|c|c|c|c|c|}
\hline Construct & Statement & Not at all & Minimal & Strong & $\mathbf{N}$ & Mean & $\begin{array}{l}\text { Standard } \\
\text { Deviation }\end{array}$ \\
\hline $\begin{array}{l}\text { Content Knowledge } \\
\text { (CK) }\end{array}$ & $\begin{array}{l}\text { Subject matter of the lesson designed } \\
\text { correctly and appropriately spelt out }\end{array}$ & $\begin{array}{c}0 \\
(0.0 \%)\end{array}$ & $\begin{array}{c}2 \\
(16.7 \%)\end{array}$ & $\begin{array}{c}10 \\
(83.3 \%)\end{array}$ & 12 & 2.83 & 0.38 \\
\hline $\begin{array}{l}\text { Pedagogical } \\
\text { Knowledge (PK) }\end{array}$ & $\begin{array}{l}\text { Appropriate pedagogic approaches to } \\
\text { support learning chosen }\end{array}$ & $\begin{array}{c}0 \\
(0.0 \%)\end{array}$ & $\begin{array}{c}2 \\
(16.7 \%)\end{array}$ & $\begin{array}{c}10 \\
(83.3 \%)\end{array}$ & 12 & 2.83 & 0.38 \\
\hline $\begin{array}{l}\text { Technological } \\
\text { Knowledge (TK) }\end{array}$ & $\begin{array}{l}\text { Clear design or use of computer } \\
\text { application(s) that enhance(s) the } \\
\text { lesson comprehension }\end{array}$ & $\begin{array}{c}0 \\
(0.0 \%)\end{array}$ & $\begin{array}{c}5 \\
(41.7 \%)\end{array}$ & $\begin{array}{c}7 \\
(58.3 \%)\end{array}$ & 12 & 2.58 & 0.51 \\
\hline $\begin{array}{l}\text { Pedagogical Content } \\
\text { Knowledge (PCK) }\end{array}$ & $\begin{array}{l}\text { Appropriate blend of content and } \\
\text { pedagogic approaches to achieve the } \\
\text { goals of the lesson }\end{array}$ & $\begin{array}{c}0 \\
(0.0 \%)\end{array}$ & $\begin{array}{c}5 \\
(41.7 \%)\end{array}$ & $\begin{array}{c}7 \\
(58.3 \%)\end{array}$ & 12 & 2.58 & 0.51 \\
\hline $\begin{array}{l}\text { Technological } \\
\text { Content Knowledge } \\
\text { (TCK) }\end{array}$ & $\begin{array}{l}\text { Align computer application(s) with } \\
\text { the goal(s) of the lesson }\end{array}$ & $\begin{array}{c}0 \\
(0.0 \%)\end{array}$ & $\begin{array}{c}6 \\
(50.0 \%)\end{array}$ & $\begin{array}{c}6 \\
(50.0 \%)\end{array}$ & 12 & 2.50 & 0.52 \\
\hline $\begin{array}{l}\text { Technological } \\
\text { Pedagogical } \\
\text { Knowledge (TPK) }\end{array}$ & $\begin{array}{l}\text { Appropriate use of computer } \\
\text { application(s) to support teaching } \\
\text { approach }\end{array}$ & $\begin{array}{c}0 \\
(0.0 \%)\end{array}$ & $\begin{array}{c}4 \\
(33.3 \%)\end{array}$ & $\begin{array}{c}8 \\
(66.7 \%)\end{array}$ & 12 & 2.66 & 0.49 \\
\hline $\begin{array}{l}\text { Technological } \\
\text { Pedagogical Content } \\
\text { knowledge (TPACK) }\end{array}$ & $\begin{array}{l}\text { Appropriate blend of content, } \\
\text { pedagogy and computer } \\
\text { application(s) within the lesson plan }\end{array}$ & $\begin{array}{c}0 \\
(0.0 \%)\end{array}$ & $\begin{array}{c}4 \\
(33.3 \%)\end{array}$ & $\begin{array}{c}8 \\
(66.7 \%)\end{array}$ & 12 & 2.66 & 0.49 \\
\hline Total & & & & & & 2.66 & 0.46 \\
\hline
\end{tabular}

clustered closely around the mean. The teacher-participants performed better in the lesson plans than in their self-reported knowledge of technology, pedagogy and content.

\section{Discussion of the Findings}

Before the teacher-participants took part in the professional development model, teacher-participants were administered a pre-training questionnaire formulated with Likert Scale test items. The pre-training questionnaire was made up of the same seven constructs notably TK, CK, PK, PCK, TCK, TPK and TPACK to determine teachers training needs in terms of technology, pedagogy and content knowledge. Teacher-participants reported a better mastery of content knowledge (CK), Pedagogical Content Knowledge (PCK), pedagogical knowledge (PK) and Technological Content Knowledge (TCK). On the other hand, they reported weaknesses in: Technology Knowledge (TK); Technological Pedagogical Knowledge (TPK) and Technological Pedagogical Content Knowledge (TPACK) constructs. After attending a 10-week professional development programme carried out once every week in a 2-hour face-to-face mode, post-training survey questionnaires was administered. The analysed data showed improvement in all seven constructs.

Teacher-participants improved performance after their participation in the professional development programme can be attributed to the three key aspects that constitute the MASLEPT model. Firstly, prior to their participation in the professional development programme, their learning needs were assessed using instruments adapted from the TPACK framework (Schmidt, Baran, Thompson, Koehler, Mishra, \& Shin, 2009; Archambault \& Crippen, 2009). Mishra and Koehler (2006) in their study had demonstrated that the 21st century teacher should have a firm mastery of technology, pedagogy and contentment knowledge as an amalgamation to effectively teach using technology in their classroom. The assessment of their skills prior to their participation in the professional development programme enabled the researcher to identify their specific training needs and design content to address them. The MASLEPT model strongly encourage trainers to ensure that professional development programmes respond to teachers' needs (Nkwenti Ndongfack, 2015).

Secondly, Lesson Study as a component of the MASLEPT model argues that if teachers work in a group over an extended period of time to design lessons, implement them, get feedback, and improve on their practice, such lessons will be great (Baba \& Kojima, 2004; Fernandez \& Yoshida, 2004; Stigler \&Hiebert, 1999). During the professional development programme that lasted for ten weeks, the researcher played the role of a facilitator. Teachers developed several lesson plans collaboratively, implemented it within themselves and got feedback 
from colleagues for improvement purposes. Research lessons are authentic instructional packages taught by the teacher to their own class (Baba \& Kojima, 2004). All the lesson plans developed were based on the school curriculum and which covered topics that had not been taught for the current school year. With the challenges the teacher-participants had while delivering the lessons in previous years the professional development programme empowered them on how to use technology to address them. The MASLEPT model emphasise on the fact that professional development programmes should address the problems teachers face in their classroom. Based on this aspect, teachers took the training programme serious because it addresses the problems they directly face in their classroom.

Thirdly, teacher interaction is a very critical component of the MASLEPT model (Nkwenti Ndongfack, 2015). Social Constructivist theory argues that learning occurs through socio-cultural mediation (Vygotsky, 1978). This means that teachers will construct new knowledge through their active participation in the professional development programme and via interactions with various learning technologies. As teachers work collaboratively during the professional development programme, the more knowledgeable ones with technological skills support the less experienced colleagues. The MASLEPT model reinforces this practice because it enables teachers in a professional development programme to come together to set technological lesson goals, plan the lessons, implement them and reflect on its outcomes.

Lewis and Tsuchida (1997) uphold that when teachers work through the lesson study cycle as seen in the MASLEPT model, they produce authentic classroom lessons that are focused on a specific pre-determined problem, goal, or expected learning outcome. Since the teachers work collaboratively, the lessons were carefully planned, observed by other teachers, analysed and reflected upon by group members, administrators or an invited commentator. In such processes, social constructivism was very much in action because social negotiations, discussions, reflections and explanations lead to a positive learning outcome (Rock \& Wilson, 2005 as cited in Nkwenti Ndongfack, 2015). Collaborative lesson planning improves the effectiveness of the learning experiences teachers provide to their pupils. When teachers learn collaboratively, it becomes eminent that they will engage pupils in collaborative learning activities (Fraser, 2005 as cited in Nkwenti Ndongfack, 2015). These three aspects contributed greatly in the outcome of the professional development programme driven by the MASLEPT model.

\section{Implication for Teacher Trainers}

The content of this professional development programme was developed based on the outcome of a trainingneeds analysis conducted with teacher-participants. The lesson study approach guided the process of the professional development programme and TPACK developmental stages guided the teachers' progress as they develop their knowledge of technology, pedagogy and content as a combination (Nkwenti Ndongfack, 2015).

Professional development content that is clearly structured, easy, appropriately sequenced and includes activities to assist teachers in the construction of their own knowledge from previous experiences produces effective teachers. The activities should be related to authentic classroom situations in order to increase teachers' interest in the programme and make learning fun (Mishra \& Koehler, 2006). These experiences should be provided in an environment that is comfortable for teachers to explore, experiment and practice with the tools and content. Furthermore, activities that are designed to be completed collaboratively produce quality results and build professional relationships whereby expert teachers support the less knowledgeable ones. Collaborative practices that yield better results are those that enable expert teachers or facilitators from within the group to carry out demonstration exercises that are beneficial to teachers with less experience in technology integration into lessons (Nkwenti Ndongfack, 2015). In short, the design of a professional development programme for teachers is very crucial for a successful rollout of the programme.

To ensure that the professional development model is sustainable, practitioners should incorporate into the design a facilitator who is capable of providing clear, effective, and timely feedback to teachers. The facilitator should also be able to model best practices and ensure teachers are engaged throughout the professional development programme. Modelling best practices to teachers is very important because most teachers tend to replicate the activities and practices they learn during professional development programmes into their own teaching practices (Fraiser, 2005). Depending on the availability of a facilitator to implement the programme, practitioners may have to design and develop a facilitator's guide. This guide would be created to assist the facilitator with the implementation of the intended programme. Additional training sessions with the facilitator might be 
necessary depending on the facilitator's technological skills. The designer should consider the facilitator's availability at the beginning of the professional development process, so they can plan accordingly and work within the timeline for implementation.

\section{Conclusion}

The purpose of this study was to experiment the use of the MASLEPT school-based professional development model in the development of primary school teachers' knowledge of technology, pedagogy and content. The results indicated teacher-participants who took part in the experimentation of the MASLEPT professional development model demonstrated a significant improvement in their technological pedagogical content knowledge. To test whether improvement had any statistical significant difference, the mean of the two test results was compared using t-test. The findings indicated that $p=0.005<0.05$. It was therefore concluded that there was a statistically significant difference between the scores of the two means (pre-training and post-training). Therefore teacher-participants' technological pedagogical content knowledge improved as a result of their participation in the proposed professional development model. This finding was further triangulated by comparing the scores of the lesson notes produced by the teacher-participants with the post-training scores. It was found that the scores of each construct of the lesson notes were better than the post-training scores.

\section{References}

Archambault, L., \& Crippen, K. (2009). Examining TPACK among K-12 Online Distance Educators in the United States. Contemporary Issues in Technology and Teacher Education, 9, 71-88. http://www.citejournal.org/vol9/iss1/general/article2.cfm

Baba, T., \& Kojima, M. (2004). Lesson Study. In: The History of Japan's Education Development: What Implications Can Be Drawn for Developing Countries? Institute for International Development, Tokyo: JICA.

Becker, J. H., \& Riel, M. M. (2001). Teacher Professional Engagement and Constructivist Compatible Computer Use. Report No. 7, Teaching, Learning, and Computing Project [Online]. http://www.crito.uci.edu/tlc/findings/report_7

Borko, H. (2004). Professional Development and Teacher Learning: Mapping the Terrain. Educational Researcher, 33, 3-15. http://dx.doi.org/10.3102/0013189X033008003

Dewey, J. (1916). Democracy and Education. An Introduction to the Philosophy of Education. New York: Free Press.

Fernandez, C., \& Yoshida, M. (2004). Lesson Study: A Japanese Approach to Improving Mathematics Teaching and Learning. Mahwah, NJ: Lawrence Erlbaum.

Fru, M. (2011). ICT Readiness in Cameroon Primary Schools: A Case Study of Some Primary Schools Yaounde 6 Sub-Division. A Dissertation Submitted in Partial Fulfilment of an Award of a Master's Degree in Education, Yaounde, Cameroon: University of Yaounde I.

Gray, B. (2004). Informal Learning in an Online Community of Practice. Journal of Distance Education, 19, 20-35.

Guskey, T. R. (2002). Professional Development and Teacher Change. Teachers and Teaching: Theory and Practice, 8, 381391. http://dx.doi.org/10.1080/135406002100000512

Hanley, P., Maringe, F., \& Ratcliffe, M. (2008). Evaluation of Professional Development: Deploying a Process-Focused Model. International Journal of Science Education, 30, 711-725. http://dx.doi.org/10.1080/09500690701854899

Harris, J., Grandgenett, N., \& Hofer, M. (2010). Testing a TPACK-Based Technology Integration Assessment Instrument. In C. D. Maddux, D. Gibson, \& B. Dodge (Eds.), Research Highlights in Technology and Teacher Education 2010 (pp. 323-331). Chesapeake, VA: Society for Information Technology and Teacher Education (SITE).

Harris, J., Mishra, P., \& Koehler, M. (2009). Teachers’ Technological Pedagogical Content Knowledge and Learning Activity Types: Curriculum-Based Technology Integration Reframed. Journal of Research on Technology in Education, 41, 393-416. http://dx.doi.org/10.1080/15391523.2009.10782536

Harris, J. B., \& Hofer, M. (2011). Technological Pedagogical Content Knowledge in Action: A Descriptive Study of Secondary Teachers' Curriculum-Based, Technology-Related Instructional Planning. Journal of Research on Technology in Education, 43, 211-229. http://dx.doi.org/10.1080/15391523.2011.10782570

Harrison, C., Comber, C., Fisher, T., Haw, K., Lewin, C., Lunzer, E., McFarlane, A., Mavers, D., Scrimshaw, P., Somekh, B., \& Watling, R. (2002). ImpacCT2: The Impact of Information and Communication Technologies on Pupil Learning and Attainment. London: DfES and Becta.

Hashimoto, Y, Tsubota, K., \& Ikeda, T. (2003). Ima Naze Jugyo Kenkyu Ka: Sansujugyo no Saikochiku [Why Lesson Study Now: Restructuring Math Lessons]. Tokyo: Toyokan-Shuppan. 
Holland, B. (2005). Real Change in Higher Education: Understanding Differences in Institutional Commitment to Engagement. In A. Kezar, T. Chambers, \& J. Burkhardt (Eds.), Higher Education for the Public Good: Emerging Voices from a National Movement (pp. 235-259). San Francisco, CA: Jossey-Bass Publishers.

Inspectorate of Pedagogy in Charge of ICT (2009). Annual Report on the Teaching and Learning of ICT across the School Curriculum.

Inspectorate of Pedagogy in Charge of ICT (2010). Annual Report on the Teaching and Learning of ICT across the School Curriculum.

Inspectorate of Pedagogy in Charge of ICT (2011). Annual Report on the Teaching and Learning of ICT across the School Curriculum.

Karsenti, T., Collin, S., \& Harper-Merrete, T. (2012). Pedagogical Integration of ICT: Success and Challenges from 100+ African Schools. Ottawa, ON: IDRC.

Koehler, M. J., \& Mishra, P. (2008). Introducing Technological Pedagogical Content Knowledge. In AACTE Committee on Innovation and Technology (Ed.), Handbook of Technological Pedagogical Content Knowledge (TPCK) for Educators (pp. 3-29). New York: Routledge.

Lewis, C., \& Tsuchida, I. (1997). Planned Educational Change in Japan: The Case of Elementary Science Instruction. Journal of Educational Policy, 12, 313-331. http://dx.doi.org/10.1080/0268093970120502

Lieberman, A., \& Pointer Mace, D. H. (2008). Teacher Learning: The Key to Educational Reform. Journal of Teacher Education, 59, 226-234. http://dx.doi.org/10.1177/0022487108317020

Macdonald, R. J. (2009). Professional Development for Information Communication Technology Integration: Identifying and Supporting a Community of Practice through Design-Based Research. Journal of Research on Technology in Education, 40, 429-445. http://dx.doi.org/10.1080/15391523.2008.10782515

Mishra, P., \& Koehler, M. J. (2006). Technological Pedagogical Content Knowledge: Anew Framework for Teacher Knowledge. Teachers College Record, 108, 1017-1054. http://dx.doi.org/10.1111/j.1467-9620.2006.00684.x

Nkwenti Ndongfack, M. (2010). ICT Integration in Cameroon Primary Schools: A Case Study of Government Primary Practicing School Angele, South Region. A Dissertation Submitted in Partial Fulfillment of an Award of a Master's Degree in Instructional Design and Technology, Malaysia: Open University.

Nkwenti Ndongfack, M. (2015). Mastery of Active and Shared Learning Processes for Techno-Pedagogy (MASLEPT): A Model for Teacher Professional Development on Technology Integration. Creative Education, 6, 32-45. http://dx.doi.org/10.4236/ce.2015.61003

Republic of Cameroon, Ministry of Basic Education (Inspectorate of Pedagogy in charge of Computer Science Education) (2007) Information and Communication Technology Framework and Strategies Plan for Basic Education Sub-Sector.

Richardson, S. (2009). Mathematics Teachers’ Development, Exploration, and Advancement of Technological Pedagogical Content Knowledge in the Teaching and Learning of Algebra. Contemporary Issues in Technology and Teacher Education [Online Serial], 9. http://www.citejournal.org/vol9/iss2/mathematics/article1.cfm

Richey, R. C. (2005). Validating Instructional Design Models. In J. M. Spector \& D. A. Wiley (Eds.), Innovations in Instructional Technology: Essays in Honor of M. David Merrill (pp. 171-185). Mahwah, NJ: Lawrence Erlbaum Associates, Publishers.

Richey, R. C., \& Klein, J. (2007). Design and Development Research: Methods, Strategies, and Issues. Mahwah, NJ: Lawrence Erlbaum Associates, Publishers.

Rock, T. C., \& Wilson, C. (2005). Improving Teaching through Lesson Study. Teacher Education Quarterly, 32, 77-92.

Schmidt, D. A., Baran, E., Thompson, A. D., Koehler, M. J., Shin, T. S., \& Mishra, P. (2009). Technology, Pedagogy and Content Knowledge (TPACK): The Development and Validation of an Assessment Instrument for Pre-Service Teachers. Journal of Research on Technology in Education, 42, 123-149.

Schwille, J., \& Dembélé, M. (2007). Global Perspective on Teacher Learning. Improving Policy and Practice. Paris: IIEP/UNESCO.

Selinger, M. (2001). Learning Information and Communications Technology Skills and the Subject Context of the Learning. Journal of Information Technology for Teacher Education, 10, 143-154. http://dx.doi.org/10.1080/14759390100200108

Shulman, L. S. (1986). Those Who Understand: Knowledge Growth in Teaching. Educational Researcher, 15, 4-14. http://dx.doi.org/10.3102/0013189X015002004

Shulman, L. S. (1987). Knowledge and Teaching: Foundations of the New Reform. Harvard Educational Review, 57, 1-22.

Valanides, N., \& Angeli, C. (2006). Preparing Pre-Service Elementary Teachers to Teach Science through Computer Models. Contemporary Issues in Technology and Teacher Education-Science, 6, 87-98.

Villegas-Reimers, E. (2003). Teacher Professional Development: An International Review of the Literature. Paris: UNESCO International Institute for Educational Planning. 
Vygotsky, L. S. (1962). Thought and Language. Cambridge, MA: MIT Press.

Vygotsky, L. S. (1978). Mind in Society: The Development of Higher Psychological Processes. Cambridge, MA: Harvard University Press.

Wenger, E. (1998). Communities of Practice: Learning, Meaning, and Identity. Cambridge, UK; New York, NY: Cambridge University Press. http://dx.doi.org/10.1017/CBO9780511803932

Wenger, E., McDermott, R. A., \& Snyder, W. (2002). Cultivating Communities of Practice: A Guide to Managing Knowledge. Boston, MA: Harvard Business School Press.

Yoon, K. S., Duncan, T., Lee, S. W., Scarloss, B., \& Shapley, K. L. (2007). Reviewing the Evidence on how Teacher Professional Development Affects Student Achievement. Issues \& Answers Report, REL 2007-No. 033. Washington DC: US Department of Education, Institute of Education Sciences, National Center for Education Evaluation and Regional Assistance, Regional Educational Laboratory Southwest. 